
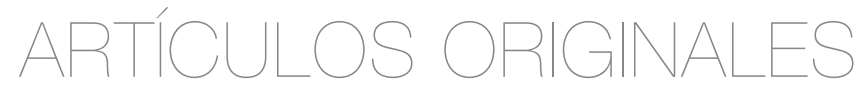

\title{
Purchases for corporate needs in Russia's regions in 2019
}

\author{
IULIIA PINKOVETSKAIA* \\ ANTON LEBEDEV** \\ ELENA SVERDLIKOVA***
}

* PhD in Economics. Ulyanovsk State University, Ulyanovsk, Russia. E-mail: judy54@yandex.ru. ORCID: 0000-0002-8224-9031. Google Scholar: https://scholar.google.com/citations?view_op=list_works\&hl=ru\&user=-ktJB3oAAAAJ. Scopus Author ID: https://www. scopus.com/authid/detail.uri?authorld=57192312196.

** PhD in Culture. Mordovia State University, Saransk, Russia. E-mail: toshaleb@mail.ru. ORCID: 0000-0002-1927-5595.Google Scholar: https://scholar.google.com/citations?view_op=list_works\&hl=ru\&user=e-w1SXoAAAAJ.

*** PhD in Economics. Lomonosov Moscow State University, Moscow, Russia. E-mail: elena.sverdlikova@gmail.com. ORCID: 0000-0001-6730-5078. Google Scholar: https://scholar.google.com/citations?view_op=list_works\&hl=ru\&user=lfPMIR4AAAAJ. 
COMO CITAR ESTE ARTÍCULO How to cite this article:

Pinkovetskaia, I., Lebedev, A. and Sverdlikova, E. (2021). Purchases for corporate needs in Russia's regions in 2019. Revista Perspectiva Empresarial, 8(1), 27-35.

Recibido: 28 de enero de 2021 Aceptado: 30 de junio de 2021
ABSTRACT Objective. To consider the indicators that characterize purchases for the needs of large corporations with state participation in the regions of Russia. Methodology. The study uses relevant information for 82 regions of Russia. The methodology of the research base on evaluation functions density of normal distribution volumes of contracts on regions. Results. The results of research are calculation of four indicators' values that demonstrate the regional aspects of procurement for corporate needs, including the contracts signed by small businesses or with their participation. Conclusions. It was proved that average share of the contracts with small enterprises is about $20 \%$; the value of every indicator is significantly varied in different regions of Russia. The article confirms the lack of connection between the values of each indicator and such factors as the level of economic development of regions and their geographical location.

KEYWORDS Contract system, corporate procurement, regions of Russia, Unified Information System.

\section{Compras para necesidades corporativas en las regiones de Rusia en 2019}

RESUMEN Objetivo. Considerar los indicadores que caracterizan las compras para las necesidades de las grandes empresas con participación estatal en las regiones de Rusia. Metodología. El estudio utiliza información relevante para 82 regiones de Rusia. La metodología de la investigación se basa en la densidad de las funciones de evaluación de los volúmenes de distribución normal de los contratos en las regiones. Resultados. Los resultados de la investigación son el cálculo de los valores de cuatro indicadores que demuestran los aspectos regionales de la contratación para las necesidades corporativas, incluyendo los contratos firmados por las pequeñas empresas o con su participación. Conclusiones. Se demostró que la proporción media de los contratos con las pequeñas empresas es aproximadamente del $20 \%$; el valor de cada indicador varía significativamente en las distintas regiones de Rusia. El artículo confirma la falta de relación entre los valores de cada indicador y factores como el nivel de desarrollo económico de las regiones y su ubicación geográfica.

PALABRAS CLAVE sistema de contratos, contratación empresarial, regiones de Rusia, Sistema de Información Unificado. 


\section{Compras para necessidades corporativas nas regiões da Rússia em 2019}

RESUMO Objetivo. Considere os indicadores que caracterizam as compras para as necessidades de grandes empresas com participação estatal nas regiões da Rússia.

Metodologia. 0 estudo usa informações relevantes para 82 regiões da Rússia. A metodologia da pesquisa é baseada na densidade das funções de avaliação dos volumes de distribuição normal dos contratos nas regiões. Resultados. Os resultados da pesquisa são o cálculo dos valores de quatro indicadores que demonstram os aspectos regionais da contratação para atender às necessidades corporativas, incluindo contratos firmados por pequenas empresas ou com sua participação. Conclusões. A proporção média de contratos com pequenas empresas mostrou-se em torno de $20 \%$; o valor de cada indicador varia significativamente nas diferentes regiões da Rússia. 0 artigo confirma a falta de relação entre os valores de cada indicador e fatores como o nível de desenvolvimento econômico das regiões e sua localização geográfica.

PALAVRAS CHAVE sistema de contrato, contratação de negócios, regiões russas, Sistema de Informação Unificado. 


\section{Introduction}

The activities of the Russian contract system in the field of corporate procurement are organized in accordance with Federal Law No. 223-FZ of 18 July of 2011. According to the Unified Information System, the total value of contracts signed in recent years in Russia reached the following values: 18.4 trillion rubles for 2015; 22.9 trillion rubles for 2016; 19.6 trillion rubles for $2017 ; 18.2$ trillion rubles for 2018; and 20.4 trillion rubles for 2019. The decline in corporate procurement after 2016 is explained by the amendments to Federal Law No. 223-FZ, which removed a large number of contracts from the public sphere. Significant financial resources are accumulated in the procurement system for the needs of state corporations, natural monopolies, autonomous institutions and other legal entities in accordance with the above-mentioned law. Thus, in 2019, the volume of corporate purchases reached almost $19 \%$ of the country's total GDP. Corporate procurement can play a significant role in the development of the state economy and most of the country's regions.

One of the greatest achievements in the development of the contract system in Russia is the transition of all corporate procurement to the digital platform. The Unified Information System acts as such medium. In accordance with the Russian legislation, starting from 2019, when conducting competitive procurement, electronic procedures and digital workflow are mainly used, including in the signing of contracts. The Unified Information System generates real-time data sets, including purchase plans, information about their implementation, purchases and signed contracts, register of unfair suppliers; catalogues of goods, services and works for corporate needs.

As shown by the accumulated experience and research (Fernandes and Vieira, 2015; Lewis-Faupel et al., 2016; Vaidya and Campbell, 2016), digitalization of procurement can provide an increase in the efficiency of spending funds, simplify procurement procedures, reduce their time and cost. This measure can improve the quality of corporate management based on the openness and transparency of purchasing the necessary products of proper quality. In addition, it reduces bureaucratic procedures and administrative barriers, as well as eliminates personal interaction with contractors and customers. The article by Altayyar and Beaumont-Kerridge (2016) emphasizes that the digital contract system requires government support, the adoption of appropriate legislation, the development of digital infrastructure, and ensuring the security of online payments and transactions. Regional characteristics considerably affect the volume and structure of purchases for corporate needs. In particular, it is shown by the example of the Italian electronic market in operation (Albano et al., 2015).

Much attention should be paid to the issues of ensuring unhindered access to tenders for small businesses when forming a contract system. Some aspects of this problem are reflected in scientific research. For instance, the article by Stake (2017) examines the disproportionate share of contracts with small businesses in the European Union, despite the fact that the current legislation recognizes the important role of such enterprises in procurement. In a paper based on data from 271 customers in Ireland, it is proved that there is a significant difference between the actual reallife situation and the declared policy of assistance to small businesses when entering into contracts (Flynn, 2018).

The existence of the Unified Information System raises the issue of studying indicators that characterize corporate purchases, as well as obtaining new data immediately after the expiration of each time period (month, quarter, year).

In the course of the research, the authors analyze the following issues: (i) The general characteristics of all corporate contracts for each region of Russia; and (ii) The characteristics of contracts involving small businesses in each region.

At the same time, the authors respond to recent calls in the literature for a more systematic study of procurement for corporate needs (Agapova and Belyaeva, 2019), including their role in supporting small businesses (Kostyuchenko, 2015). In modern conditions, in most countries, entrepreneurship is aimed at solving vital socio-economic problems, i.e., increasing competitiveness (Pinkovetskaia et al., 2020), economic growth (Kiseleva et al., 
2019) and improving the welfare of the population (Pinkovetskaia et al., 2019).

The analysis of purchases for corporate needs, including the operation of the unified information contract system in Russia, is given some attention in the study of Russian researchers (Andrianova, 2019; Barkatunov and Larina, 2019). Although the major attention is paid directly to the general issues of the procurement system and the regional features of the signed contracts, their indicators and interregional comparative analysis have not been properly reflected in the research. Taking this into account, at the present time, the study of the regional features of the contract system functioning in Russia is of the greatest relevance.

\section{Methodology}

This article discusses the regional features of competitive procurement of items, goods, and services by certain types of legal entities, listed in the provided current Federal Law No. 223. In particular, they include state corporations and companies, natural monopolies, organizations engaged in regulated activities, autonomous institutions and business entities with the authorized capital's share of state bodies exceeding $50 \%$.

The comparative analysis of the regional indicators' absolute values of corporate procurement is not appropriate, since the regions of Russia differ significantly in terms of population, socio-economic status, climate conditions, and geographicallocation, which has a significantimpact on the volume and structure of such purchases. Therefore, it is possible to compare purchases for corporate needs based on such relative indicator as the average cost of one contract for each of the regions. In accordance with Federal Law No. 223 , much attention is paid to the participation of small and medium-sized businesses - SMEin competitive procurement. In this regard, the authors analyze specific indicators that reflect corporate purchases from SMEs in the total number of contracts and their cost by regions of Russia.

The purpose of the article is to evaluate specific indicators describing regional features of goods and services' purchases for corporate needs based on information for 2019. The firstindicator describes the value of the average cost of one contract for each of the regions. The second indicator describes the involvement of SMEs in the implementation of contracts as the major holders or subcontractors (co-holders) and reflects the average cost of one such contract for the region. The third indicator is the share of contracts involving small businesses in the total number of the signed contracts. The fourth indicator is the value share of contracts that small businesses sign in the total value of all agreements. The application of specific indicators allows to conduct the comparative analysis by region, which is relevant for studying the problem of improving the contract system in Russia.

The following hypotheses are tested in the course of the study:

Hypothesis 1: currently, there are significant differences in the values of the listed indicators in different regions of Russia.

Hypothesis 2: the indicator values are not related to the geographical location of regions.

Hypothesis 3: the values of the indicators do not depend on the level of the regional economic development.

These hypotheses are based on the modeling of empirical data using the density function of the normal distribution.

As the information source, the authors use the official data of the unified information system in the field of procurement for 82 regions of Russia.

\section{Results}

This article presents the models developed by the authors, that describe the regional distribution of the values of the four indicators listed above. The development of these models is based on the relative indicators calculated by the authors, based on the data for 2019 provided on the website of the Unified Information System. As indicated earlier, the models used are density functions of the normal 
distribution. These functions $y$ describing the distribution of values of purchasing indicators for corporate needs by region $x$, are shown below:

(i) the cost of one contract, million rubles:

$$
y_{1}\left(x_{1}\right)=\frac{136.67}{2.38 \times \sqrt{2 \pi}} \cdot e^{\frac{-\left(x_{1}-4.52\right)^{2}}{2 \times 2.38 \times 2.38}}
$$

(ii) the cost of one contract involving the SME, million rubles:

$$
y_{2}\left(x_{2}\right)=\frac{133.25}{1.86 \times \sqrt{2 \pi}} \cdot e^{\frac{-\left(x_{2}-3.62\right)^{2}}{2 \times 1.86 \times 1.86}}
$$

(iii) the percentage of contracts that the SME signs, \%:

$$
y_{2}\left(x_{2}\right)=\frac{133.25}{1.86 \times \sqrt{2 \pi}} \cdot e^{\frac{-\left(x_{2}-3.62\right)^{2}}{2 \times 1.86 \times 1.86}}
$$

(iv) the share of the contracts' value involving the SME, \%:

$$
y_{4}\left(x_{4}\right)=\frac{410.01}{6.17 \times \sqrt{2 \pi}} \cdot e^{\frac{-\left(x_{4}-13.75\right)^{2}}{2 \times 6.17 \times 6.17}}
$$

The quality of the developed models is evaluated using the Kolmogorov-Smirnov, Pearson, and Shapiro-Wilk tests. Testing shows that the developed models are of high quality and correctly approximate the original data over the entire range of their changes.

\section{Discussion}

The density functions of the normal distribution (1)-(4) allow to characterize the four indicators of purchases for corporate needs in the regions of Russia under consideration. The regional average values of indicators based on functions (1)-(4) are shown in column 2 of the Table 1 . Column 3 shows the intervals for changing indicator values for most (68\%) regions. The boundaries of these intervals are calculated as follows: the average square deviations are added and subtracted from the values shown in column 2 respectively.

Table 1. Indicators that characterize regional purchases in 2019

\begin{tabular}{lll}
\hline \multicolumn{1}{c}{ Indicators } & Average values & Values, typical for most regions \\
\hline 1 & 2 & 3 \\
\hline Cost of one contract, million rubles & 4.52 & $2.14-6.90$ \\
\hline Cost of one contract, with the participation of the SME, million rubles & 3.62 & $1.76-5.48$ \\
\hline Share of the contracts involving the SMEs, \% & 19.24 & $12.46-27.02$ \\
\hline Share of the contracts' value signed by the SMEs, \% & 13.75 & $7.58-19.92$ \\
\hline
\end{tabular}

Source: author own elaboration.

The table data indicates that the average regional value of contracts signed by the customers with small and medium-sized businesses (3.62 million rubles) is lower than the corresponding indicator for all the parties (4.62 million rubles). This seems logical, since some tenders are carried out by large enterprises. For the same reason, the share of the contracts with the participation of the SMEs (19.24\%) is higher than their share in the cost (13.75\%). It should be noted that according to the Decree of the Government No. 1352 of 11 December of 2014, the share of the contracts' 
value signed with the SMEs must be at least $18 \%$. The analysis shows that only 19 regions met this requirement in 2019. These are the Trans-Baikal and Krasnodar territories, Nizhny Novgorod, Omsk, Tyumen, Irkutsk, Ulyanovsk, Volgograd, Orenburg, Tambov, Astrakhan, Leningrad, Chelyabinsk, Kostroma regions, the republics of Komi, Altai, Mari El, Mordovia, and Chuvashia.

As seen from the data provided in column 2 , in 2019 the average cost per contract signed in Russia is 4.52 million rubles. For most regions, the value of this indicator is within the range from 2.1 to 6.9. The level of this indicator, greater than the upper limit of the interval, is observed in the cities of Moscow and St. Petersburg, Samara, Sverdlovsk, Kaluga, Tula, Moscow regions, the republics of Sakha (Yakutia), Tatarstan, Bashkortostan, Buryatia, as well as Krasnoyarsk and Primorsky territories. The values of the indicator below the lower limit of the interval are observed in the Belgorod, Vologda, Lipetsk, Tambov and Ivanovo regions, the republics of Kalmykia, Altai, Tuva and Chuvashia.

The average cost of a single contract involving the SME in the regions under review is 3.62 million rubles. For most regions, the value of this indicator is within the range from 1.76 to 5.48 million rubles. The level of the indicator, higher than the upper limit of the interval shown in column 3 of the table, occurs in the republics of Tuva, Tatarstan, the cities of Moscow and St. Petersburg, Krasnoyarsk and Krasnodar territories, Kostroma, Astrakhan, and Tula regions. Low values of the contracts with the SMEs (less than 1.7 million rubles) were registered in the republics of Kalmykia, Adygea, Ingushetia, Ivanovo, Novgorod, Belgorod, Pskov, Penza and Kursk regions.

Across the Russian regions, the average share of the contracts with the participation of the SMEs is $19.24 \%$. In other words, almost a fifth of the signed contracts provide for the participation of SMEs. For most regions, this figure is within the range of $12.46 \%$ to $27.02 \%$. More than $30 \%$ of purchases involving the SMEs take place in the cities of Moscow and St. Petersburg, the republics of Tatarstan, Kalmykia, Tula, Leningrad, Nizhny Novgorod, and Smolensk regions. The lowest levels of the indicator from $6 \%$ to $12 \%$ are observed in Pskov, Belgorod, Kemerovo, Sakhalin, Kaliningrad regions, the republics of Karelia, Adygea, Tuva, Buryatia and Kabardino-Balkaria.

The average regional share in the cost of the contracts involving small businesses is $13.75 \%$. For most regions, this figure is within the range of 7.58 $\%$ to $19.92 \%$. The regions with a relatively high level of this indicator (above $18 \%$ ) are shown earlier. The lowest 2019 annual values of the indicator (from $6.4 \%$ to $3.1 \%$ ) are in such regions as Pskov, Samara, Kaluga, Voronezh, Sverdlovsk, Novosibirsk, Belgorod, Novgorod regions, the republics of Adygea and Buryatia, and Primorsky Krai.

In addition to the presented study, the tabular data indicates that there is a significant differentiation in the regional values of the four indicators analyzed in the article. Thus, one can consider the proposed hypothesis 1 as confirmed. Analysis of the lists of regions with high and low values for each of the four indicators shows that both high and low values occur in the regions located in the center of the country, its North and South, as well as in the West and East. This leads to the conclusion that hypothesis 2 is valid. It is also true of hypothesis 3 , since the regions with both high and low indicators' value have the different levels of economic development.

\section{Conclusions}

Russia has multiple large corporations based on state and private property. In order to improve the efficiency of these corporations, legislative acts are adopted for them to purchase the goods and services they need in open markets, which are accessible to all enterprises, without exception. This solves the relevant problem of increasing competition and reducing the cost of purchases for the needs of corporations. The Federal Law adopted in 2011 stipulates the purchase of $18 \%$ of all the goods and services they need from small and medium-sized businesses. Consequently, this creates the prerequisites for supporting SMEs by involving them in the release of new and innovative products that large corporations demand.

The article focuses on assessing the performance of a Unified Information System 
for corporate procurement in Russia in 2019. This system works in real-time and allows all the interested businesses to submit their applications for participation in corporate procurement. The system generates data sets reflecting procurement plans, signed contracts, as well as lists of goods, services and works that customers need. The implementation of this system has shown its high efficiency and reliability; therefore, it currently contains all the information on corporate procurement in Russia. In our opinion, the further development of the system should be associated with the provision of more detailed data on each of the planned contracts, since not all customers completely disclose this information.

In the course of the research, the results obtained proved the scientific novelty and originality of the study. The authors assessed the values of four indicators that characterize the regional aspects of procurement for corporate needs, focusing on the contracts made by small and medium-sized businesses or concluded with their participation. The evaluation showed that for 2019 the average value of one contract was 4.52 million rubles, which is estimated as the high amount in the current economic conditions. The average level of the SMEs participation in procurement was 19.24 $\%$, which is higher than the legal minimum. Whereas many regions of Russia have lower level than the minimum established by law.

The study indicates the distribution of indicator values across the regions of Russia and assesses the economic and mathematical models as the density function of the normal distribution. Four functions have been developed and tested to provide a good approximation of the original empirical data. Along with the determination of the indicators' average values, these functions allowed to describe the spread of the four indicators considered in the article in all 82 regions of Russia. It showed that the regions differ in the prevailing values of each of the four indicators, since there is a significant differentiation in the values of indicators across regions. The study identified the regions that are characterized by high and low values of indicators. The authors noted that there is no correlation between the values of each indicator and such factors as the level of economic development of the regions and their geographical location.
The obtained research results offer a certain theoretical and applied significance. The study results can be used in the improvement of data processing technologies in the activities of the unified information contract system and its update. In particular, the considerable attention should be paid to categorizing information on the participation of all businesses and SMEs in the contract system by individual types of economic activity. The proposed indicators can be used in subsequent research on competitive procurement. The government and regional authorities could implement the research results in the development and application of projects and programs to improve individual contracts and the system in general. In addition, the research results are of interest to all participants in corporate procurement, both potential customers and prospective contract holders. The new data obtained can be used in the educational process of higher institutions.

Further research can be devoted to the assessment of the existing distribution of corporate purchases by type of economic activity, as well as within individual regions (by their municipalities). Since the study considered official information on corporate procurement for 2019 for all 82 regions of Russia, no restrictions were imposed on the initial empirical data.

\section{References}

Agapova, E.V. and Belyaeva, O.A. (2019). Limits of transparency of corporate procurement. Economic Sciences, 175, 18-23.

Albano, G.L. et al. (2015). Evaluating Small Businesses Performance in Public E-Procurement: Evidence from the Italian Government's E-Marketplace. Journal of Small Business Management, 53(1), 229-250.

Altayyar, A. and Beaumont-Kerridge, J. (2016). An Investigation into barriers to the adoption of e-procurement within selected SMEs in Saudi Arabia. Journal of Business and Economics, 7(3), 451-466. 
Andrianova, N.V. (2019). Information platforms in the system of state and corporate procurement. Innovation and Investment, 9, 267-271.

Barkatunov, V.F. and Larina, O.G. (2019). Elements of digital technologies, legal innovations and efficiency of financial resources management in the procurement process for state and municipal needs. Proceedings of the Southwest State University. Series: History and Law, 9(3), 53-73.

Fernandes, T. and Vieira, V. (2015). Public e-procurement impacts in small- and medium-enterprises. International Journal of Procurement Management, 8(5), 587-607.

Flynn, A. (2018). Investigating the Implementation of SME-Friendly Policy in Public Procurement. Policy Studies, 39(4), 422-443.

Kiseleva, 0. et al. (2019). Specialization and concentration of small and medium enterprises employees: Russian data. Amazonia Investiga, 8(20), 6-15.

Kostyuchenko, A.G. (2015). State and corporate procurement as a tool for support and development of small business entities. Business, Management and Law, 31, 128-131.

Lewis-Faupel, S. et al. (2016). Can Electronic Procurement Improve Infrastructure Provision? Evidence from Public Works in India and Indonesia. American Economic Journal: Economic Policy, 8(3), 258-283.

Pinkovetskaia, I. et al. (2019). Female entrepreneurship development in the Russian Federation. Amazonia Investiga, 8(18), 111-118.

Pinkovetskaia, I. et al. (2020). Small and medium enterprises in Russia and other countries. Amazonia Investiga, 9(25), 99-106.

Stake, J. (2017). Evaluating Quality or Lowest Price: Consequences for Small and Medium-Sized Enterprises in Public Procurement. Journal of Technology Transfer, 42(5), 1143-1169.
Vaidya, K. and Campbell, J. (2016). Multidisciplinary approach to defining public e-procurement and evaluating its impact on procurementefficiency. Information Systems Frontiers, 18(2), 333-348. 